\title{
The Distribution of Facial Profile Photogrammetry of High School Students in Medan
}

\author{
Hilda Fitria Lubis \\ Department of Orthodontics Faculty of Dentistry \\ University of Sumatera Utara, \\ Medan, Indonesia \\ hildadrgusu@gmail.com
}

\author{
Mimi Marina Lubis \\ Department of Orthodontics Faculty of Dentistry \\ University of Sumatera Utara, \\ Medan, Indonesia \\ mimimlbs@yahoo.com
}

\author{
Siti Bahirrah \\ Department of Orthodontics Faculty of Dentistry \\ University of Sumatera Utara, \\ Medan, Indonesia \\ nyonyaindra@yahoo.com
}

\begin{abstract}
One of the main objectives of orthodontic treatment is to improve dental and facial esthetics. The understanding of soft tissues of the face in relation to the dentoskeletal tissues is essential in esthetic orthodontic treatment. Study of soft tissue facial profile by photogrammetry provides better information on the facial morphology. This is a descriptive study with a cross sectional approach using level stratified-cluster sampling method. The subjects of this study are 200 high school students in Medan. Lateral photographs of each subject were taken and their facial profile was measured. Results: The facial profile of high school students in Medan are convex $92.5 \%$, straight $5.0 \%$, and concave $2.5 \%$. There were no significant differences in the facial profile of high school students in Medan based on gender. The facial profile of high school students in Medan is generally convex.
\end{abstract}

Keywords-high school students, facial profile, photogrammetry

\section{INTRODUCTION}

Determination of the lateral facial profile is one of the many orthodontic examinations conducted for the purpose of diagnosis and treatment planning. The value of facial profile represents the facial form and these values differ in each individual [1,2]. Despite its inability to provide complete orthodontic information, determining the facial form enables evaluation of jaw malrelation [3]. Orthodontic treatment aims to arrange the dentition to achieve facial balance as well as restoring the relationship of occlusion [4]. Achieving balance between the teeth and the facial profile is also a goal of orthodontic treatment [5]. Thus, the correction of the facial profile is an important criteria of successful treatment. Sarver et al [5] stated that for several decades, doctors had tried to determine an ideal facial proportion. The study continues to this present-day and remains an interesting topic for orthodontists as a standardized guideline for aesthetic assessment has yet been established. Facial soft tissue analysis can be done by several methods; direct method of soft tissue measurement, lateral cephalometric radiographs, and photogrammetry [6,7]. Photographs provide a good assessment of harmony between the external craniofacial structures, including the soft tissues, in addition to providing reliable measurements. Through photogrammetric analysis of the facial profile, proportionality, angular and linear measurements can be obtained [8]. Soft tissue profile standards using photogrammetry have been reported for North American, Spanish, Indians, Brazilian Caucasians, Croatians and Turkish population [9].

According to Graber there are three forms of lateral facial profile that can be viewed laterally, namely; concave, straight, and convex [1,10]. Linden [11] suggests that the facial profile of males generally presented a straighter profile compared to those of an adult female. Studies of facial profile that had previously been carried out include research by Al-Barakati [12] which states that the population of Saudi adults have more convex facial profiles than the population of Europe and America as characterized by the angle of facial convexity while among the Saudi population itself, the facial profile of women was found to be relatively more straight compared to men. Zylinski [13] on children and white young adults showed that their facial profile is relatively straight rather than children due to the upper and lower lips in young adults being more retrusive.

\section{MATERIALS AND METHODS}

This study was conducted in a descriptive manner with a cross sectional approach to obtain the facial profile of high school students in Medan. The population of this study were high school students in Medan with a total of 116.038 students from 18 government high schools and 138 private high schools in Medan based on 
the data obtained from the Sumatera Utara Education Office for the year of 2006. The sampling method used was level stratified-cluster with a total sample of 200 high school students. The inclusion criteria for this study were subjects with an age range of 15-18 years old, neither previously nor currently undergoing any orthodontic treatment, Angle Class I molar relationship with normal overjet and overbite $(2-4 \mathrm{~mm})$, mild crowded anterior teeth and diastema $\leqslant 2 \mathrm{~mm}$, not wearing dentures, has a complete set of permanent dentition (except third molars), competent lips, and possessing no facial asymmetry. The exclusion criteria were high school students with a history of fracture/trauma, history of plastic or maxillofacial surgery or refusal to participate in the study.

\section{A. Procedure of study}

1. Ethical Clearance and Informed consent: Ethical clearance was approved by submitting permission to the Health Research Ethical Committee of Sumatera Utara c/o Medical School, University of Sumatera Utara. After approval, data of the study was gathered. Informed consent, in the form of written signature, was obtained by providing explanation regarding the aim and benefits of the study before performing examination and photogrammetry.

2. Sample screening: Subjects of the study were high school students between the ages of 15 to 18 years old in Medan.

3. History taking and individual data: Subjects were then examined intraorally (with a dental mirror, dental explorer, and tweezers) and questioned according to the inclusion and exclusion criteria.

4. Lateral photographs of the subjects were taken and printed.

\section{B. Printing and measuring photo results}

After photos were printed in $3 \mathrm{R}$ size, measurements according to the Graber's facial profile method (Gl-Pog reference line as a guide for determining facial profiles) was performed with the following steps (Figure 1):

1. Points of reference noted on the lateral photo were the glabella (Gl), upper (Lca) and lower lip contour (Lcb), and pogonion (Pog).

2. Lines were drawn connecting the reference points to obtain the outline of the facial profile.

3. Facial profiles can be determined by analyzing the relationship between Lca and Lcb line with the position of the Gl-Pog line as obtained as follows: Concave: the intersection point of Lca-Lcb is behind the Gl-Pog line. Straight: the intersection point Lca$\mathrm{Lcb}$ is right on the Gl-Pog line. Convex: the intersection point of Lca-Lcb is in front of the GlPog line

4. Measurements were performed three times in each sample to obtain average results.

Before analyzing data of all sample profile photos, an intra-operator test was conducted by performing measurements on 10 profile photos, and repeating it the next day. If similar results were obtained, the validity of the measurements would be assured and the operator would be selected to analyze all sample photos.

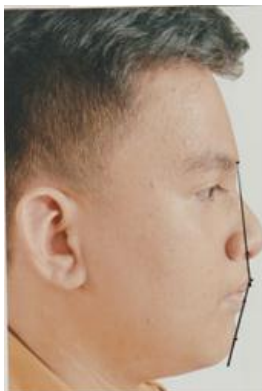

A.

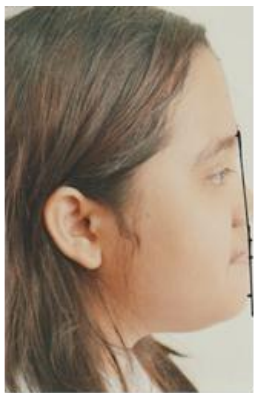

B.

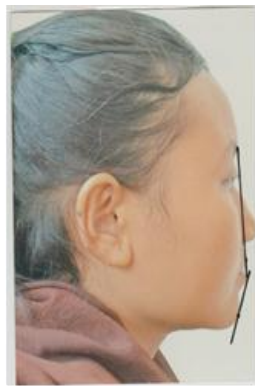

C.
Figure 1. Graber's facial profile A. Convex, B. Straight, C. Concave

\section{Processing and analyzing data}

Data of the study was processed by computerization. Data analysis begins with measurement of the respondent's photo results using reference points of facial profile photo according to Graber; the glabella, upper and lower lip contours, and pogonion with pencil. Measurements was performed on a transparent plastic sheet. The results obtained would determine the facial profile of respondent based on non-parametric method, and then be tested descriptively to analyze the facial profile.

\section{RESULTS}

This study was conducted on 200 high school students. The overall facial profile distribution of high school students in Medan based on photogrammetry were convex, with the percentage of $92.5 \%$ convex, $5 \%$ straight, and $2.5 \%$ concave ( Table I).

TABLE I. FACIAL PROFILE DISTRIBUTION OF HIGH SCHOOL STUDENTS IN MEDAN

\begin{tabular}{|c|l|c|c|}
\hline No & Facial profile & Total & Percentage (\%) \\
\hline 1 & Straight & 10 & 5.0 \\
\hline 2 & Convex & 185 & 92.5 \\
\hline 3 & Concave & 5 & 2.5 \\
\hline \multicolumn{2}{|c|}{ Total } & 200 & 100 \\
\hline
\end{tabular}

The facial profile distribution of high school students in Medan based on gender showed that there were no significant differences between facial profiles of male and female high school students in Medan (Table II).

TABLE II. FACIAL PROFILE DISTRIBUTION OF HIGH SCHOOL STUDENTS IN MEDAN BASED ON GENDER

\begin{tabular}{|c|c|c|c|c|}
\hline \multirow{2}{*}{ Gender } & \multicolumn{3}{|c|}{ Facial Profile } & \multirow{2}{*}{$\begin{array}{c}\text { P- } \\
\text { value }\end{array}$} \\
\cline { 2 - 4 } & Straight & Convex & Concave & 0.059 \\
\hline Male & $2(2,0 \%)$ & $96(97.0 \%)$ & $1(1.0 \%)$ & \\
\hline Female & $8(7.9 \%)$ & $89(88.1 \%)$ & $4(4.0 \%)$ & \\
\hline
\end{tabular}

\section{DISCUSSION}

According to Salzmann, orthodontic dentistry is a branch of science that studies the development and anomalies of the teeth and jaws that affect oral health, physical health as well as aesthetic and mental stability. Understanding the importance of oral, physical and mental health, as well as the aesthetic appearance of 
patient is necessary. The aim of orthodontic treatment according to Riedel is achievement of "Utility", "Beauty" and "Stability". Similarly, according to Jackson's Triad, orthodontic treatment goal is to maximize the function of the stomatognathic system, preserve balance of the teeth structure, skeletal and soft tissue as well as the aesthetic balance [14]. The success of orthodontic treatment is characterized by good facial appearance. The soft tissue is an important factor that determines the final appearance of the patient's face [12].

Soft tissue facial profile analysis plays an important role in orthodontic treatment planning. Orthodontic treatment according to the accepted hard tissue cephalometric criteria does not necessarily ensure that overlying soft tissues will be positioned in a harmonious manner and hence, may not result in an esthetic profile. Soft tissue of the face requires an independent appraisal in addition to the skeletal and dental analysis in order to deduce a comprehensive diagnosis and treatment planning of the face. Soft tissue cephalometric norms for esthetic profiles had been established by various researchers using cephalometric radiographs. Recently, many studies had been conducted on the photographic evaluation of soft tissue facial profiles in some racial groups [15]. Stoner [16] had started to analyze facial soft tissues using photographic records. Farkas [16] standardized the photographic technique by taking the records in natural head position (NHP). The reliability of the photogrammetry, especially for the measurement of the lips and mouth was assessed, strongly recommended and suggested that the benefits of photogrammetry can be increased by developing better techniques.

The facial appearance is subjective as it is influenced by various factors such as race, ethnic, gender, sociocultural, and age [7]. Due to the differences in perception, clinicians should consider the suitable normal value of the ideal facial appearance based on the patient's race and ethnicity when planning a treatment $[6,17]$. Ideal facial appearance is influenced by the soft tissue that covers the skeletal tissue [16]. Facial profile is one of soft tissue component that has to be examined for orthodontic diagnosis [18]. Table 1 shows that the overall facial profile distribution of high school students in Medan was convex $92.5 \%$, straight $5 \%$, and concave $2.5 \%$. The results of this study were similar to Kosoemahardja [6] that stated the soft tissue profile of Mongoloid race were more protrusive than of Caucasian. Heryumani stated that the facial profile tends to be convex on Javanese due to the nose and chin being less protrusive [6].

Table 2 shows no significant differences between male and female facial profiles among high school students in Medan. Heryumani [6] examined the facial sagittal proportions of males and females in Java and found that the nose's depth, lip to sagital nasal tip distance and chin to sagital nasal tip distance in Javanese males and females were convex. Mauchamp and Sassiouni [19] studied on effects of gender on the measurement of soft tissue facial profile as pogonion
(Pog), subnasal (Sn), and the convexity face profile. Their study reveals that female Caucasoid facial profile was found to be more straight compared to males between the ages 20-25 years old,. According to Subtelny [20] due to the thickness of the soft tissue covering the bony tissue, males were found to be more convex than females. Hambelton [21] found that male facial profile less convex than female, claiming it was due to the growth of the chin in men forming an angle greater than females. Palestinian adults showed skeletal profile convexity and this value was increased significantly in men $(5.6 \pm 1.8 \mathrm{~mm})$ compared with women $(4.5 \pm 2 \mathrm{~mm})$ [22]. Ioi et al [23] stated that Japanese facial profile was highly convex for both males and females as both genders have a tendency of retruded lip position. Reddy et al [24] after calculating the total angular facial profile (G-Prn-Pg), it was found that the population of northern India has a nose more aquiline causing the facial profile to be more straight compared to the Europeans, and by calculating the angle G-Sn-Pg, the facial profile of the female population of north India were more convex than men. Anibor and Okumagba [25] stated that the higher values shown by the Urhobo females in their Nasomental and Mentocervical values and the lesser values in the Nasofrontal and Nasofacial angles compared to males imply that the females have a more protruded nose, less prominent glabella and bigger chin on their faces compared to males. In a facial profile study by Ferdousi AM, et al., on Bangladesh Christian Garo population, the angle of facial convexity was found to be higher in females $\left(169.26^{\circ} \pm 4.43^{\circ}\right)$ than males $\left(158.65^{\circ} \pm 12.17^{\circ}\right)$, similar to that in the North Indian population and White European population. The higher convexity in females could be explained by the fact that in general the facial contours of females were softer than those of males, especially in the area of the nose, lips and chin [26].

Therefore, clinical investigations are recommended and greatly needed to obtain the facial profile according to all races and ethnics in Indonesia.

\section{ACKNOWLEDGMENT}

The authors would like to express our appreciation to the University of Sumatera Utara for providing their fund for this research.

\section{REFERENCES}

[1] R.E. Moyers, Handbook of orthodontic. $4^{\text {th }}$ ed., London: Year Book Medical Publisher Inc., 1998, pp. 171-3.

[2] S.E. Bishara, Textbook of orthodontic. Philaddephia: W.B Saunders Company, 2001, pp. 44-52.

[3] S. Samawi, A short guide to clinical digital photography in orthodontics, Jordan: Sdoc, 2008, pp. 12-6.

[4] S.I. Bhalajhi, Orthodontics: the art and science. $3^{\text {rd }}$ ed., New Delhi: Arya (Medi) Publishing House, 2004, pp. 115, 121-122, 133.

[5] D. M. Sarver, J.L. Aeckerman, "Orthondtics about face: The reemergency of the esthetic paradigm," Am. J. Orthod. Dentofac., pp. 575-576, May 2000.

[6] Heryumani. Facial profile of javanese adult based on nose, lip and chin proportion," Indonesia J. of Dent., vol. 13(3), pp. 146149, 2006.

[7] V. Moshkelgosha, S. Fathinejad, Z. Pakizeh, M. Shamsa, A. Golkari, "Photographic facial soft tissue analysis by means of 
linear and angular measurements in an adolescent persian population,” The Open Dent. J., vol. 9, pp. 346-56, 2015.

[8] H.N. Da Rocha Fortes, T.C. Guirmaraes, I.M.L. Belo, E.N.R. Da Matta, "Photometric analysis of esthetically pleasant and unpleasant facial profile," Dental Press J. Orthod., vol., 19(2), pp. 66-75, 2014

[9] O.E. Loveday, F.H. Babatunde, U.A. Isobo, O.G. Sunday, O. Ijeoma, "Photogrammetric analysis of soft tissue profile of the face of Igbos in Port Harcourt," Asian J. Med Sci., vol. 3(6), pp. 228-233, 2011.

[10] T.M. Graber, R.L Vanarsdall, Orthodontics current principles and technique, $3^{\text {rd }}$ ed., St. Louis: Mosby, 2000, 13-6, 80, 378.

[11] V.D. Linden VD, Facial growth and facial orthopedics. Chicago: Quintesence Publishing Co. Ltd, 1986, 175-192.

[12] S.F. Albarakati, "Soft tissue facial profile of adult Saudis: lateral cephalometric analysis," Saudi Med. J., vol. 32(8), pp. 836-842, 2011.

[13] C.G. Zylinski, "Analisys of soft tissue fasial profile in white males," AJODO, vol. 101, pp. 514-518, 1992.

[14] G. Singh, Textbook of orthodontics, $2^{\text {nd }}$ ed., New Delhi: Jaypee, 2007 , pp. 3-4, 67-9, 128-30.

[15] M.M. Stoner, "A photometric analysis of the facial profile," American Journal of Orthodontics, vol. 41, pp. 453-469, 1955.

[16] L.G. Farkas, W. Bryson, J. Klotz, "Is photogrammetry of the face reliable," J. Plast. Reconst. Surg., vol. 3, pp. 346-355, 1980.

[17] T. Rakosi, I. Jonas, T.M. Graber, Color atlas of dental: Orthodontic diagnosis, New York: Thieme Medical Publisher Inc., 1993, pp. 173-175.
[18] W.R. Proffit, H.W. Fields, D.M Sarver, Contemporary orthodontics. $4^{\text {th }}$ ed., St. Louis: Mosby Elsevier, 2007, pp. 17981, 191-195.

[19] D. Maucham, Sassouni, "Growth and prediction of skeletal and soft tissue profile,” AJODO., vol. 64, pp. 83-94, 1973.

[20] J.D. Subtelny, "A longitudinal study of soft tissue facial structures and their profile characteristics, defined in relation to underlying skeletal structures," AJODO., vol. 7, pp. 481-507, 1959.

[21] R. Hambleton, "The soft tissue covering of the skeletal face as related to orthodontic problems," AJODO., vol. 50, pp. 405-420, 1964.

[22] A. AI Taki, E. Abuhijleh, L. Al-Shafei, "Soft tissue profile values in Palestinian adults," Smile Dent J., vol. 8(1), pp. 26-29, 2013.

[23] H. Ioi, S. Nakata, A. Nakasima, A. Counts, "Effect of facial convexity on antero-posterior lip positions of the most favored Japanese facial profiles," Angle Orthod., vol. 75(3), pp. 326332.

[24] M. Reddy, N.K. Ahuja, P. Raghav, V. Kundu, V. Mishra, "A computer-assisted angular photogrammetric analysis of the soft tissue facial profile of north Indian adults," J. Ind. Orthod. Soc. vol. 45(3), pp. 119-23, 2011.

[25] E. Anibor, M.T. Okumagba, "Photometric facial analysis of the Urhobo ethnic group in Nigeria," Arch. Apll. Sci. Res., vol. 2(3), pp. 28-32, 2010

[26] M.A. Ferdousi, A. Al Mamun, L.A. Banu, S. Paul, "Angular photogrammetric analysis of facial profile of the adult Bangladeshi Garo," Adv. Anthropol., vol. 3(4), pp. 188-192, 2013. 